\title{
Ocular surface disorders in dogs and cats submitted to dissociative anesthesia in
}

\section{elective orchiectomy procedure}

\author{
Distúrbios da superfície ocular em cães e gatos submetidos à anestesia dissociativa em \\ procedimento de orquiectomia eletiva \\ Trastornos de la superficie ocular en perros y gatos sometidos a anestesia disociativa en un \\ procedimiento de orquiectomía electiva
}

Ana Karoline Rodrigues da Costa ORCID: https://orcid.org/0000-0001-6671-8099 Universidade Federal do Oeste da Bahia, Brazil E-mail: karolrdac@gmail.com

Danilo Rocha de Melo

ORCID: https://orcid.org/0000-0003-4793-7338 Universidade Federal do Oeste da Bahia, Brazil E-mail: danilomelo.vet@gmail.com

Jaine Mendes Lopes

ORCID: https://orcid.org/0000-0001-8886-3502 Universidade Federal do Oeste da Bahia, Brazil E-mail: jainemendeslopes@gmail.com

Mirlam de Oliveira Sampaio Júnior ORCID: https://orcid.org/0000-0003-4217-305X Universidade Federal do Oeste da Bahia, Brazil E-mail:mirlamoliveirasjr@gmail.com

Marcos Wilker da Conceição Santos ORCID: https://orcid.org/0000-0002-6357-1236 Universidade Federal do Oeste da Bahia, Brazil E-mail: vilker.mwcs@gmail.com Jessica Fontes Veloso ORCID: https://orcid.org/0000-0001-8183-0628 Universidade Federal do Oeste da Bahia, Brazil E-mail: jessica.veloso@ufob.edu.br

Caio Victor Damasceno Carvalho ORCID: https://orcid.org/0000-0001-7633-1250 Universidade Federal do Oeste da Bahia, Brazil E-mail: caio.carvalho@ufob.edu.br

Wagner Rocha de Souza ORCID: https://orcid.org/0000-0002-3781-9699 Universidade Federal do Oeste da Bahia, Brazil E-mail: wagner.souza@ufob.edu.br

Larissa José Parazzi

ORCID: https://orcid.org/0000-0002-4093-7901 Universidade Federal do Oeste da Bahia, Brazil E-mail: larissa.parazzi@ufob.edu.br Alexandra Soares Rodrigues ORCID: https://orcid.org/0000-0001-6821-4142 Universidade Federal do Oeste da Bahia, Brazil

E-mail: alexandra.rodrigues@ufob.edu.br

Layze Cilmara Alves da Silva Vieira ORCID: https://orcid.org/0000-0002-1850-2768 Universidade Federal do Oeste da Bahia, Brazil E-mail: layze.cilmara@hotmail.com

Deusdete Conceição Gomes Júnior ORCID: https://orcid.org/0000-0003-0928-0961 Universidade Federal do Oeste da Bahia, Brazil E-mail: deusdete.gomes@ufob.edu.br

\begin{abstract}
The present study aims to verify whether dogs and cats submitted to dissociative anesthesia for elective orchiectomy may present alterations in the tear production and consequent lesions on the ocular surface. For this purpose, 40
\end{abstract}


animals, 22 cats and $18 \mathrm{dogs}$, underwent an ophthalmic semiotechnique composed of the evaluation of anterior and posterior chambers, fundscopy, Schirmer's tear test (TLS) and fluorescein test. Subsequently, they underwent dissociative anesthesia, associating ketamine with diazepam or midazolam. Immediately at the end of the procedure, the fluorescein and TLS test was repeated. After 24 hours, a new ophthalmic evaluation was performed to compare the results obtained. There were no ophthalmic changes. With the use of diazepam, TLS remained within the normal range with a median of $19 \mathrm{~mm} / \mathrm{min}$, with a mean and standard deviation of $19.27 \pm 3.01 \mathrm{~mm} / \mathrm{min}$ for dogs and a median of $18 \mathrm{~mm} / \mathrm{min}$, with a mean and standard deviation of $19.05 \pm 2.81 \mathrm{~mm} / \mathrm{min}$ for cats. When using midazolam, the TLS of the dogs had a median of $19 \mathrm{~mm} / \mathrm{min}$, with a mean and standard deviation of $18.84 \pm 2.69$ $\mathrm{mm} / \mathrm{min}$ and of the cats, they had a median of $18 \mathrm{~mm} / \mathrm{min}$ with a mean and standard deviation of $18.37 \pm 2.32 \mathrm{~mm} /$ min. The results found suggest that the use of dissociative anesthesia for short procedures does not significantly alter the tear production, nor does it cause eye injuries.

Keywords: Keratitis; Ketamine; Diazepam; Midazolam.

\section{Resumo}

O presente trabalho tem por objetivo verificar se cães e gatos submetidos a anestesia dissociativa para orquiectomia eletiva podem apresentar alterações na produção lacrimal e consequente lesões na superfície ocular. Para tal, 40 animais, 22 gatos e 18 cães, foram submetidos a semiotécnica oftálmica composta pela avaliação de câmaras anterior e posterior, fundoscopia, teste lacrimal de Schirmer (TLS) e teste da fluoresceína. Posteriormente, foram submetidos a anestesia dissociativa associando-se a cetamina ao diazepam ou midazolam. Imediatamente ao término do procedimento foi repetido o teste da fluoresceína e TLS. Após 24 horas uma nova avaliação oftálmica foi realizada para comparação dos resultados obtidos. Não houveram alterações oftálmicas. Com uso do diazepam o TLS se manteve dentro da normalidade apresentando mediana de $19 \mathrm{~mm} / \mathrm{min}$, com média e desvio padrão de $19.27 \pm 3.01$ $\mathrm{mm} / \mathrm{min}$ para cães e mediana de $18 \mathrm{~mm} / \mathrm{min}$, com média e desvio padrão de $19.05 \pm 2.81 \mathrm{~mm} / \mathrm{min}$ para gatos. Ao utilizar o midazolam, o TLS dos cães apresentou mediana de $19 \mathrm{~mm} / \mathrm{min}$, com média e desvio padrão de $18.84 \pm 2.69$ $\mathrm{mm} / \mathrm{min}$ e dos gatos tiveram mediana de $18 \mathrm{~mm} / \mathrm{min}$ com média e desvio padrão de $18.37 \pm 2.32 \mathrm{~mm} / \mathrm{min}$. Os resultados encontrados sugerem que o emprego da anestesia dissociativa para procedimentos curtos não altera a produção lacrimal significativamente, nem ocasiona lesões oculares.

Palavras-chave: Ceratite; Cetamina; Diazepam; Midazolam.

\section{Resumen}

El presente trabajo tiene como objetivo verificar si los perros y gatos sometidos a anestesia disociativa para orquiectomía electiva pueden presentar alteraciones en la producción de lágrimas y consecuentes lesiones en la superficie ocular. Para ello, 40 animales, 22 gatos y 18 perros, fueron sometidos a una semiotécnica oftálmica compuesta por la evaluación de cámaras anterior y posterior, fondoscopia, prueba de lágrimas de Schirmer (TLS) y prueba de fluoresceína. Posteriormente, fueron sometidos a anestesia disociativa, asociando ketamina con diazepam o midazolam. Inmediatamente al final del procedimiento, se repitió la prueba de fluoresceína y TLS. A las 24 horas se realizó una nueva evaluación oftálmica para comparar los resultados obtenidos. No hubo cambios oftálmicos. Con el uso de diazepam, el SLT se mantuvo dentro del rango normal con una mediana de $19 \mathrm{~mm} / \mathrm{min}$, con una desviación media y estándar de 19,27 \pm 3,01 mm / min para perros y una mediana de $18 \mathrm{~mm} / \mathrm{min}$, con una media y estándar desviación de 19,05 \pm 2,81 mm / min para gatos. Al utilizar midazolam, la SLT de los perros tuvo una mediana de 19 $\mathrm{mm} / \mathrm{min}$, con una media y desviación estándar de 18,84 $\pm 2,69 \mathrm{~mm} / \mathrm{min}$ y de los gatos, una mediana de $18 \mathrm{~mm} /$ min con una media y estándar desviación de 18,37 $\pm 2,32 \mathrm{~mm} / \mathrm{min}$. Los resultados encontrados sugieren que el uso de anestesia disociativa para procedimientos cortos no altera significativamente la producción de lágrimas ni causa lesiones oculares.

Palabras clave: Queratitis; Ketamina; Diazepam; Midazolam.

\section{Introduction}

The eye is a photosensitive organ responsible for the perception of the external environment as well as objects and light intensity (Junqueira \& Carneiro, 2004), which allows communication with other body systems through sensory responses (Olbertz, 2012). It consists of three tunics: fibrous or external, vascular or intermediate and nervous or internal. The fibrous tunic shapes the eye and comprises the cornea and sclera (Silva, 2017).

The cornea is the anterior portion of the fibrous chamber, which allows refraction and transmission of light due to its transparency and shape (Cook, 2013). Has a wide range of sensory nerves and is avascular which makes its supply necessary, especially with oxygen and metabolites provided by aqueous humor and tear film (TF) (Junqueira \& Carneiro, 2004). In addition, eyelids guarantee the necessary protection against external environment (Stades \& Woerdt, 2013). 
The eyelids protect the ocular structures and assist in the spread of the TF during its movement (Tuner, 2010). TF is composed by two layers, one lipid and another aqueous-mucin (Fonseca et al., 2010). The lipid portion is responsible for reducing tear evaporation, which prevents eye damage (Andrade, 2014; Davidson \& Kuonen, 2004), while the aqueous-mucin portion moistens and nourishes the cornea and provides adhesion and protection to the ocular surface (Liebchi et al., 2016).

During general anesthesia due to decreased corneal reflex and absence of eyelid movements, the ocular surface dryness may occur and has already been reported consequently to the decreased of tear production (Kocatürk et al., 2012). This predisposes the occurrence of corneal lesions in dogs and cats (Pontes et al., 2010; Komnenou et al., 2013) making it necessary to use preventive measures to reduce the severity of injuries such as the use of eye lubricants, ointments or tear gel during surgical procedures (Kara et al., 2015).

On the other hand, in dissociative anesthesia, a technique routinely used in veterinary medicine, especially in low complexity procedures, or in regions that do not have technologies and qualified personnel to perform general anesthesia, the animals remain with their eyes open, but with the protective reflexes maintained, once the eyelid reflex is stimulated, the animal contracts ipsilateral eyelids In addition, the use of dissociative anesthesia predisposes to the increase of secretions, including lacrimals (Raposo et al., 2015), however, it is unknown if they reduce the aqueous fraction of the FT or predispose to the occurrence of lesions on the ocular surface.

The ocular system is routinely neglected during the pre-surgical evaluation, which can predispose the occurrence of injuries and cause additional pain and discomfort to the animal in the post-surgical period, being the ophthalmic examination of great importance for the diagnosis of eye disorders and among the techniques routinely used in the ophthalmic routine, the Schirmer tests stand out, a semi-quantitative method that assesses the aqueous production of the tear film and the fluorescein test, a water-soluble dye, which has the characteristic of being retained by hydrophilic structures, mainly staining the corneal stroma. in cases of injuries, allowing the visualization of the alteration (Maggs, 2017) which can be better visualized with a cobalt filter, allowing its diagnosis and, consequently, treatment.

Given the gaps in the literature on the occurrence of lesions on the corneal surface in animals submitted to dissociative anesthesia protocols, common in patients undergoing general anesthesia (Howard et al., 1965), and because the aqueous fraction of TF of dogs and cats submitted to dissociative anesthesia before and immediately after the surgical procedure, this work was carried out.

\section{Methodology}

This study was approved by the Ethics Committee on Animal Experimentation of the Use of Animals from the Federal University of Western of Bahia (protocol no. 8/2019). All procedures were conducted in accordance with the Association for Research in Vision and Ophthalmology's (ARVO) Statement for the Use of Animals in Ophthalmic and Vision Research and NIH statement.

The methodology chosen for the present study was quantitative (Pereira et al., 2018), where, forty healthy animals, being 18 dogs and 22 cats, attended at the Veterinary University Hospital of the Federal University of Western of Bahia (HVUUFOB), who underwent elective orchiectomy under dissociative anesthesia were consigned (Macphail, 2015; Berdnarski, 2017).

To perform the anesthetic-surgical procedure, the animals underwent a general clinical examination, complete blood count (CBC) and ophthalmic evaluation to rule out lesions on the ocular surface, using the Schirmer tear test (STT) (Drogavet ${ }^{\circledR}$ Salvador, Bahia, Brazil) to semi-quantitatively assess the aqueous production of TF, based on reference values ranging from 15 to $25 \mathrm{~mm} / \mathrm{min}$ for dogs (Maggs, 2017) and 9 to $34 \mathrm{~mm} / \mathrm{min}$ for cats (Sebbag et al., 2015), use of fluorescein 
strips (Drogavet ${ }^{\circledR}$ Salvador, Bahia, Brazil) with objective of identifying lesions on cornea. Also an evaluation of the anterior and posterior chambers and fundoscopy was made with the aid of Panoptic (Welch Allyn®, Skaneateles Falls, New York, USA). Animals that showed any alterations of the tests were excluded from the study.

To perform the surgical procedure, a 10-hour food fast and a 6-hour water fast were requested. The use of diazepam or midazolam was defined at random. The animals of diazepam group received intravenously, in cephalic vein, diazepam $\left(0.5 \mathrm{mg} \mathrm{kg}^{-1}, 0.5 \%\right.$, diazepam, Hipolabor, Belo Horizonte, Brazil). The animals of midazolam group received intramuscularly, in the posterior region of the right thigh (semimembranous or semitendinosus muscle), midazolam $\left(0.5 \mathrm{mg} \mathrm{kg}^{-1}, 0.1 \%\right.$, Dormire ${ }^{\circledR}$, Cristália do Brasil S/A, São Paulo, Brazil). This was followed by the application of Ketamine $\mathrm{S}+\left(10 \mathrm{mg} \mathrm{kg}^{-1}, 5 \%\right.$, Cristália do Brasil S/A, Brazil) in the posterior region of the left thigh. After administration of the drugs, the animals were kept in an environment without stressors. Relaxation of the animal was observed approximately 5 to 10 minutes after application, followed by trichotomy, venous access, administration of tramadol (Tramal ${ }^{\circledR}, 4 \mathrm{mg} \mathrm{kg}^{-1}, 5 \%$ tramadol hydrochloride, Hipolabor, Belo Horizonte, Brazil) subcutaneously, and local anesthesia with lidocaine (Xylestesin® 2\%, Cristália do Brasil S / A, São Paulo, Brazil) in the incision line and near the spermatic cord.

The animals' eyes were not manipulated during the anesthetic-surgical procedure to avoid interference. Orchiectomy was performed routinely using the scrotal technique (Macphail, 2015). Immediately after the surgical procedure, performed between 5 to 10 minutes, the STT was performed to assess the tear production. An ophthalmic evaluation was performed 24 hours after the procedure to identify if there were lesions in the ocular surface.

The Shapiro-Wilk test was performed to verify the normality of the data. The Mann-Whitney non-parametric test was followed to identify changes if there were changes before or after anesthesia.

\section{Results and Discussion}

The 40 animals in the study were divided into groups. The group of cats consisted of 22 animals, where 10 were anesthetized with ketamine and diazepam and 12 with ketamine and midazolam. The group of dogs consisted of 18 animals, where 10 were anesthetized with ketamine and diazepam and 8 with ketamine and midazolam.

The lacrimal production of dogs and cats submitted to dissociative anesthesia using ketamine associated with diazepam showed a median of $19 \mathrm{~mm} / \mathrm{min}$, with a mean and standard deviation of $19.27 \pm 3.01 \mathrm{~mm} / \mathrm{min}$ for dogs and $19.05 \pm$ $2.81 \mathrm{~mm} / \mathrm{min}$ for cats. There was no significant effect before and after anesthesia for dogs and cats $(p=0.173 ; p=0.383$, respectively). In dissociated anesthesia with the use of ketamine associated with midazolam, the dogs had a median of 19 $\mathrm{mm} / \mathrm{min}$, with a mean and standard deviation of $18.84 \pm 2.69 \mathrm{~mm} / \mathrm{min}$, and the cats had a median of $18 \mathrm{~mm} / \mathrm{min}$ with a mean and standard deviation of $18.37 \pm 2.32 \mathrm{~mm} / \mathrm{min}$, with no significant effect before and after anesthesia $(p=0.261 ; p=0.967$, respectively). All results found in the STT were within the reference values for the species (Maggs, 2017; Sebbag et al., 2015).

When evaluating the effects of sedatives associated with opioids on the tear production of dogs, it was observed that the use of acepromazine and oxymorphine, diazepam and butorphanol, xylazine and butorphanol caused a significant reduction in tear production. The use of xylazine alone did not significantly alter the tear production, which suggests that in association with butorphanol there is a mechanism that reduces tear production, but there was no evaluation of butorphanol in isolation (Dodam et al., 1998).

In a study with non-human primates, it was found that dissociative anesthesia increases secretions, including lacrimal anesthesia (Raposo et al., 2015), this fact may justify the increase in the values of the STT found in most animals in the present study and absence of corneal lesions in all animals. It should be noted that despite dissociative anesthesia maintaining 
protective reflexes, as the eyelid reflex (Rezende, 1983), these were not stimulated during the evaluations, returning to their function according to the responses of each animal during the anesthetic recovery.

The absence of corneal lesions and maintenance of normality in the values of tear production identified through the STT found in this study differ from that observed in humans submitted to general anesthesia for 90 minutes using propofol and isoflurane (Kocatürk et al., 2012) where it was observed a decrease in tear production resulting in ocular dryness which predisposing to the occurrence of corneal lesions (Komneu et al., 2013) and reinforces the need of the anesthetist to use eye lubricants, ointments or tear gel to minimize the injures, especially in surgeries lasting 2 hours or more (Kara et al., 2015). It must be considered that inhalation anesthesia is normally used in more prolonged procedures, differing from the present study where the procedures were of short duration.

\section{Conclusion}

Dissociative anesthesia is widely used in veterinary practice, but there are few studies on its action in the eyes of animals. No significant changes were observed in the present study, it is suggested that dissociative anesthesia does not significantly alter the production of tears and does not favor the occurrence of lesions on the corneal surface of dogs and cats in short-term procedures.

Finally, in future studies, it is suggested that other surgical procedures that have a longer anesthetic time can be explored regarding the possibility of changes in the ocular surface. Furthermore, they seek to elucidate the role of these drugs when affecting other ophthalmic structures, in addition to the ocular surface, to minimize risks for individuals submitted to the most diverse veterinary anesthetic protocols.

\section{References}

Andrade, A. L. (2014). Semiologia do sistema visual dos animais domésticos; In: F.L. Feitosa (Org), Semiologia Veterinária: A arte do diagnóstico. Semiologia do Sistema Visual dos Animais Domésticos (3a e), Cap.14, pp. 690-718. Roca.

Berdnarski, R. M. (2017). Anestesia e analgesia para espécies domésticas. In: K. A. Grim et al (Ed.), Lumb \& Jones: Anestesiologia e Analgesia em Veterinária (5a ed.), Cap. 2, pp. 44-89. Roca.

Cook, C. S. (2013). Ocular Embryology and Congenital Malformations. In: K.N. Gelatt, Veterinary ophthalmology (5a ed.), Cap.14, pp. 15-17. WileyBlackwell.

Davidson, H. J., \& Kuonen, V. J. (2004). The tear film and ocular mucins. Veterinary Ophthalmology, 7(2), 71-77.

Dodam, J. R., Brason, K. R., \& Martin, D. D. (1998). Effects of intramuscular sedative and opioid combinations on tear production in dogs. Veterinary Ophthalmology, 1(1), 57-59.

Fonseca, E. C., Arruda, G. V., \& Rocha, E. M. (2010). Olho seco: etiopatogenia e tratamento. Arquivos Brasileiros de Oftalmologia, 73(2), 197-203.

Howard, R. T. J., Kearns, T. P., Love, J. G. \& Orwoll, G. (1965).Untoward Ophthalmic and Neurologic Events of Anesthesia. Surgical Clinics of North America, 45(4), 927-938, 1965.

Junqueira, L. C., \& Carneiro, J. (2004). Sistema Fotorreceptor e Audiorreceptor. In: L.C. Junqueira \& J. Carneiro (Orgs), Histologia Básica Texto/Atlas (10a ed., Cap.23, pp.497-515): Guanabara Koogan.

Kara, N., Jr., Espindola, R. F., Valverde Filho, J., Rosa, C. P., Ottoboni, A., \& Silva, E. D. (2015). Ocular risk management in patients undergoing general anesthesia: an analysis of 39,431 surgeries. Clinics, 70(8), 541-543.

Kocatürk, O., Kocatürk, T., Kaan, N., \& Dayanir, V. (2013). The Comparison of Four Different Methods of Perioperative Eye Protection under General Anesthesia in Prone Position. Journal of Clinical and Analytical Medicine, 3(2), 163-165, 2013.

Komnenou, A. T. H., Kazakos, G. M., Savvas, I., \& Thomas, A. L. N. (2013). Evaluation of aqueous tear production in dogs after general anaesthesia with medetomidine-propofol-carprofen-halothane. Veterinary Record, 173 (6), 142-142.

Liebchi, H. G., Sótoniy, P., \& Konig, H. E. (2016). Olho (Oculos). In: H. E. König \& H.G. Liebich (Org.), Veterinary anatomy of domestic mammals (6a ed.), Cap.16, pp. 579-600, Artmed.

Macphail, M. C. (2015). Cirurgia dos Sistemas Reprodutivo e Genital. In: T.W. Fossum (Ed.), Cirurgia de Pequenos Animais (4a ed.), Cap. 27 , pp. $2240-2247$. Elsevier. 
Research, Society and Development, v. 10, n. 3, e38710313466, 2021

(CC BY 4.0) | ISSN 2525-3409 | DOI: http://dx.doi.org/10.33448/rsd-v10i3.13466

Maggs, D.J . (2017). Basic Diagnostic Techniques. In: D. J. Maggs, P. E. Miller, R. Ofri (Orgs.), Slatter's Fundamentals of Veterinary Oph thalmology (6a ed.), Cap.5, pp. 85-102, Saunders Elsevier.

Olbertz, L. (2012) Levantamento clínico-epidemiológico com análise morfológica das principais neoplasias oculares em cães (Tese de mestrado). Faculdade de Ciências Agrárias, Universidade Federal do Paraná, Paraná, PR, Brasil.

Pereira, A. S., Shitsuka, D. M., Parreira, F. J., \& Shitsuka, R. (2018). Como escrever um artigo científico. In A. S. Pereira, D. M. Shitsuka, F. J. Parreira \& R. Shitsuka (Orgs.), Metodologia da Pesquisa Científica. Cap.6, pp. 100-103. Santa Maria.

Pontes, K. C. S., Borges, A. P. B., Eleotério, R. B., Ferreira, P. S., \& Duarte, T. S. (2010). A comparison of the effects of Propofol and Thiopental on tear production in dogs. Revista Ceres, 57(6), 757-761.

Raposo, A. C. S., Ofri, R., Schaffer, D. P. H., Gomes, D. C., Jr., Libório, F. A., Martins Filho, E. F. \& Oriá, A. P. (2015). Evaluation of ophthalmic and hemodynamic parameters in capuchin monkeys (Sapajus sp.) submitted to dissociative anesthetic protocols. Journal Medical Primatology, 44(6), 318-389.

Rezende, M. A. C. (1983). Emprego do cloridrato de ketamina, associado as acepromazina e droperidol, na indução da anestesia geral pelo fluotano em equinos (Tese mestrado). Escola de Veterinária, Universidade Federal de Minas Gerais, Minas Gerais, MG, Brasil.

Sebbag, L., Kass, P. H., \& Maggs, D. J. (2015). Reference values, intertest correlations, and test-retest repeatability of selected tear film tests in healthy cats. Journal of the American Veterinary Medical Association, 246 (4), 426-435.

Silva, A. C. E. (2017). Oftalmologia veterinária. Editora e Distribuidora Educacional S.A.

Stades, F. C., \& Woerdt, A. V. (2013). Diseases and Surgery of the Canine Eyelid. In: K.N. Gelatt (Org.), Veterinary ophthalmology (5a ed.), Cap.13, pp. 832835. Wiley-Blackwell.

Tuner, S. M. (2010). Párpados. In: S.M. Tuner (Org.), Oftalmología de pequeños animales. Cap. 1 , pp. 24-26, Elsevier. 